\title{
Erratum: Stress Varies Along the Social Density Continuum
}

\section{Frontiers Production Office*}

Frontiers Media SA, Lausanne, Switzerland

\section{OPEN ACCESS}

Approved by:

Frontiers Editorial Office, Frontiers Media SA, Switzerland

*Correspondence: Frontiers Production Office production.office@frontiersin.org

Received: 24 September 2021 Accepted: 24 September 2021

Published: 05 October 2021

Citation:

Frontiers Production Office (2021) Erratum: Stress Varies Along the

Social Density Continuum. Front. Syst. Neurosci. 15:782630. doi: 10.3389/fnsys.2021.782630

\section{An Erratum on} doi: 10.3389/fnsys.2020.582985
Keywords: social isolation, stress, social density, crowding, brain modifications

\section{Stress Varies Along the Social Density Continuum}

by Love, J., and Zelikowsky, M. (2020). Front. Syst. Neurosci. 14:582985.

Due to a production error, the Editor's note was included in the Editor's affiliation.

The publisher apologizes for this mistake.

The original article has been updated.

Copyright $\odot 2021$ Frontiers Production Office. This is an open-access article distributed under the terms of the Creative Commons Attribution License (CC BY). The use, distribution or reproduction in other forums is permitted, provided the original author(s) and the copyright owner(s) are credited and that the original publication in this journal is cited, in accordance with accepted academic practice. No use, distribution or reproduction is permitted which does not comply with these terms. 